\title{
Patient Safety in Transfusion Medicine
}

\author{
Segurança do Doente em Medicina Transfusional
}

\author{
Ana Isabel Simão Teles ${ }^{*}$ \\ ${ }^{1}$ Instituto Português do Sangue e da Transplantação - Avenida do Brasil, n²1, Pavilhão 17, 1749-005 Lisboa. \\ Email: anateles7@hotmail.com
}

* This work was developed underr the Master for Health Units Management, from the Universidade Lusófona, Lisboa. * Este trabalho foi desenvolvido para obtenção do grau de Mestre em Gestão de Unidades de Saúde, ECTS - ULHT, Lisboa.

\begin{abstract}
Patient safety is a new area gaining ground and many followers. In the past two decades, many international organizations have developed initiatives to increase knowledge in this area.

We might consider that patient safety focuses on the study of the impact of adverse events resulting from the provision of health care for patients. This dimension cuts across all healthcare areas because every care is always underlying the risk-benefit binomial. Transfusional medicine is no exception. Transfusion safety includes not only the safety of blood and blood components as a therapeutic product, but also the safety of the transfusion process. The transfusion process involves a large set of steps and actors, which generates a complex network of processes' interactions and multidisciplinary professionals. This complexity provides an environment prone to the occurrence of adverse events. The majority of these events are the result of errors occurring throughout the transfusion chain and may have a negative impact on the health of the patient. Errors can trigger adverse reactions in patients with varying consequences, which can range from 'minor' situations, through various states of morbidity and even death.
\end{abstract}

Keywords: Patient Safety, Transfusion Medicine, Near Misses, Incidents, Adverse Transfusion Reactions.

\section{Resumo}

A segurança do doente é uma área recente que tem vindo a ganhar terreno e bastantes seguidores. Nas duas últimas décadas, vários organismos internacionais têm desenvolvido iniciativas com vista a aumentar conhecimento nesta área.

Pode considerar-se que a segurança do doente se debruça no estudo do impacto dos eventos adversos decorrentes da prestação de cuidados de saúde nos doentes. Esta dimensão é transversal a todas as áreas da saúde, pois em cada prestação de cuidados está sempre subjacente o binómio risco-benefício. E a medicina transfusional não é excepção.

A segurança transfusional engloba não só a segurança do sangue e dos componentes sanguíneos como produto terapêutico, mas também a segurança do processo transfusional.

Esse processo envolve um enorme conjunto de etapas e de intervenientes, o que gera uma complexa rede de interacções de processos e de profissionais multidisciplinares. Tal complexidade proporciona um "ambiente favorável" à ocorrência de eventos adversos. A maioria desses eventos é o resultado de erros que ocorrem ao longo de toda a cadeia transfusional e, podem ter um impacto negativo na saúde do doente. Os erros podem desencadear reacções adversas no doente com consequências variáveis, que podem ir desde situações 'minor', passando por diversos estados de morbilidade e, até à morte.

Palavras-Chave: Segurança do Doente, Medicina Transfusional, Quase-erros, Erros, Reacções Adversas em Receptores. 


\section{Patient Safety: from past to present}

The concept of patient safety emerged steadily in the $1990 \mathrm{~s}$, based on the premise that although the power of modern medicine to improve the patient's health is unquestionable, hospitals were not in fact safe places. In 2000, the biggest impact was felt, however, when the American report To Err is Human, of the Institute of Medicine (IOM), revealed that 44,000 to 98,000 people died every year by preventable adverse events in health care providers in the US, identifying this as the eighth leading cause of death and one of the most serious public health problems. ${ }^{(1)}$

This area has gained a greater focus by the fact that there are incidents that cause harm to patients and involve huge costs, and that a significant portion of these incidents could be avoided. However, this is still a bit of a utopian concept due to the obstacles which must be faced. This is mainly due to the healthcare organizations complexity, the multifactorial nature of the situations that are behind the safety failures, and the sensitivity of the subject ${ }^{(2)}$.

Errors and adverse events can result from various areas and different levels of health care, such as the government support and funding, the institutional structures and processes, or the interaction between patient and health providers ${ }^{(3)}$.

Since results in patient safety are based on a comprehensive set of factors, this aroused interest from the scientific and political communities, and resulted in the realization of numerous studies and publications, as well the introduction of the topic on the political agendas of many countries.

The World Health Organization (WHO) recognized patient safety as a priority, and developed several action plans leading to the implementation of initiatives in healthcare institutions around the world, alongside the European Commission (EC) initiatives. Some of these initiatives are described in Figure 1.

\section{Segurança do Doente: do passado ao presente}

O conceito de segurança do doente surgiu, de forma mais constante, na década de 1990, com base na premissa de que embora sendo inquestionável o poder da medicina moderna para melhorar a saúde dos doentes, os hospitais não eram de facto lugares seguros. No entanto, o maior impacto foi sentido, quando em 2000 foi publicado o relatório norte-americano To Err is Human, do Institute of Medicine (IOM), onde se revelava que morriam entre 44 mil e 98 mil pessoas por ano, devido a eventos adversos evitáveis em unidades prestadoras de cuidados de saúde nos EUA, identificando-os como a oitava causa de morte e como um dos problemas mais graves de saúde pública ${ }^{(1)}$.

Esta área ganhou um maior enfoque pelo facto de existirem incidentes que causam dano nos doentes, que implicam custos enormes e que uma parte significativa destes incidentes pode ser evitada. No entanto, trata-se de um conceito ainda utópico face aos obstáculos com que se tem deparado. Isto deve-se essencialmente à complexidade das organizações de saúde, ao carácter multifactorial das situações que estão por detrás das falhas de segurança e à sensibilidade do tema ${ }^{(2)}$.

Os erros e os eventos adversos podem ser o resultado de várias áreas e de distintos níveis dos cuidados de saúde, como por exemplo ao nível do apoio governamental como o financiamento, ao nível institucional nas estruturas e processos, ou a interacção entre doentes e profissionais de saúde como é exemplo o erro humano ${ }^{(3)}$.

Visto os resultados em segurança do doente se enunciarem com base num abrangente conjunto de factores, este facto despertou a comunidade científica e política, que resultou na realização de inúmeros estudos e publicações, bem como a sua introdução nas agendas políticas de muitos países.

A Organização Mundial de Saúde (OMS) reconheceu a segurança do doente como uma área prioritária, e desenvolveu vários planos de acção que culminaram com iniciativas implementadas em instituições de saúde em todo o mundo, a par das iniciativas da Comissão Europeia $(\mathrm{CE})$. Algumas destas iniciativas encontram-se esplanadas nas Figura 1.

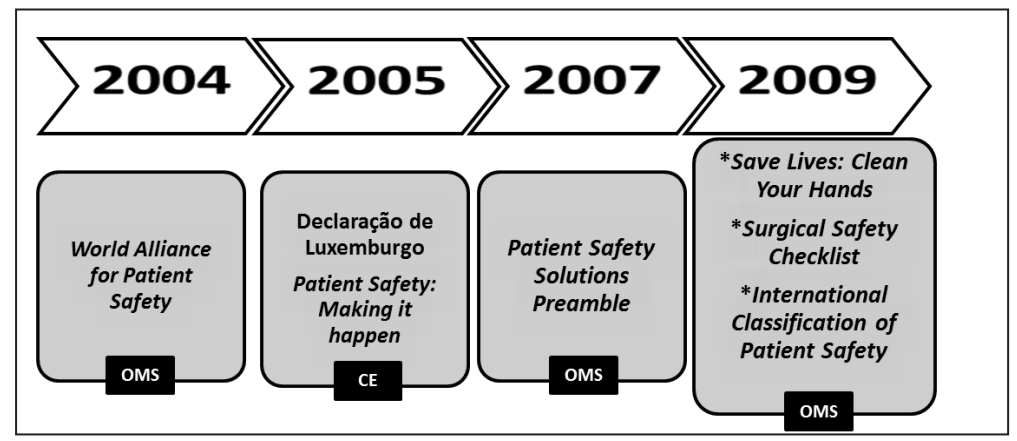

Figure 1/ Figura 1. Examples of initiatives in Patient Safety by the WHO and EC

Exemplos de iniciativas em Segurança do Doente pela OMS e CE. 
The creation of a universal vocabulary and defining concepts in this area was essential so that various studies could be compared, promoting further understanding by the scientific community, more robust information and the development of guidelines perceived by all. It can be accepted that the patient safety focuses the impact of adverse events arising from the provision of health care for patients. Adverse events can be directly related to an inadequate and/or improper care practice. Several published studies shows that preventable adverse events are a global problem, and prevention of these events has been a common goal, since the damage can be fatal for patients, and their occurrence generates an enormous consumption of resources at all levels.

\section{Transfusion Safety: transfusion medicine from the perspective of patient safety}

Transfusion Medicine is an integral part of modern health care. This is the therapeutic use of blood and blood components, or, in other words, the blood transfusion. Blood transfusion is the infusion of a volume of blood or blood component from a healthy donor to a patient. This has both prophylactic and therapeutic functions. If properly used, it can save lives and improve the patient health. However, like other medical practices, it is not without risks. Patient safety is transversal to all areas of health, because every care underlies in the risk-benefit binomial, and transfusion medicine is no exception.

Currently there are unquestionable therapeutic benefits from transfusion, however, throughout history there are examples where failures generated by the risks exceeded its therapeutic power. Permanent scientific and technological advances overcame those doubts, and finally, after a few centuries, transfusional medicine was recognized as a safe practice. But fears persist, and although the risks of yesterday are not the risks of today, it is certain that it is impossible to eliminate them completely (zero risk is a utopia), thus efforts must be made to prevent those which are preventable.

The transfusion safety encompasses not only the safety of blood and blood components as a therapeutic product, but also the safety of the transfusion process. This process involves a huge set of steps and actors, which creates a complex network of interactions and processes of multidisciplinary professionals. Such complexity provides an "enabling environment" to the occurrence of adverse events. The majority of these events are the result of errors occurring throughout transfusion chain and these events may have a negative impact on the
A criação de um vocabulário universal e a definição de conceitos nesta área era essencial, para que estudos variados pudessem ser susceptíveis a comparação, um maior entendimento por parte da comunidade científica, a criação de informação mais robusta e a criação de guidelines compreendidas por todos de igual modo. Pode considerar-se que a segurança do doente, se debruça no estudo do impacto dos eventos adversos decorrentes da prestação de cuidados de saúde nos doentes. Os eventos adversos podem estar directamente relacionados com uma prática inadequada e incorrecta de cuidados. Os vários estudos publicados mostram que os eventos adversos evitáveis são um problema global, daí que a prevenção destes eventos tem sido um objectivo comum, uma vez que os danos causados nos doentes podem ser fatais e a sua ocorrência gera um enorme consumo de recursos a todos os níveis.

\section{Segurança Transfusional: a medicina transfusional na perspectiva da segurança do doente}

A Medicina Transfusional é uma parte integrante da moderna assistência à saúde. Esta consiste na utilização terapêutica do sangue e dos componentes sanguíneos, ou seja, da transfusão sanguínea. A transfusão de sangue consiste na perfusão de um determinado volume de sangue ou componente sanguíneo, proveniente de um dador saudável, a um doente. Esta tem simultaneamente funções profilácticas e terapêuticas. Se usada correctamente pode salvar vidas e melhorar a saúde dos doentes. No entanto, tal como as demais práticas médicas, não é isenta de riscos. A segurança do doente é transversal a todas as áreas da saúde, pois em cada prestação de cuidados está sempre subjacente o binómio riscobenefício, e a medicina transfusional não é excepção. Actualmente são inquestionáveis os benefícios terapêuticos da transfusão, no entanto ao longo da história foram vários os momentos em que as falhas geradas pelos riscos superaram o seu poder terapêutico. Os constantes avanços científicos e tecnológicos fizeram com que essas dúvidas fossem ultrapassadas e, finalmente passados alguns séculos a medicina transfusional foi reconhecida como uma prática segura. Mas os receios persistem e embora os riscos de ontem não sejam os riscos de hoje, certo é que eliminá-los por completo, ou seja o risco zero é uma utopia, cabendo-nos apenas a satisfação de prevenir os que são evitáveis.

A segurança transfusional engloba não só a segurança do sangue e dos componentes sanguíneos como produto terapêutico, mas também a segurança do processo transfusional. Este processo envolve um enorme conjunto de etapas e de intervenientes, o que gera uma complexa rede de interacções de processos e de profissionais multidisciplinares. Tal complexidade proporciona um "ambiente favorável" à ocorrência de eventos adversos. A maioria desses eventos é o resultado de erros que ocor- 
health of the patient. Errors can trigger adverse reactions in patients with varying consequences, which can range from 'minor' situations, through various states of sickness, and even death. But the errors can be detected before starting a transfusion and as such, would not reach the patient. In this case we refer to near misses. Although they do not have consequences to the patient, near misses are an important source of information and education, allowing the identification of process weaknesses, with the possibility of timely restructure, thereby creating barriers of prevention.

\section{Hemovigilance: a transfusion safety monitoring tool}

Under these concerns, and alongside the patient safety issue, hemovigilance emerged in the early 1990s, as a security concept. The EU defines Hemovigilance as an organized system within the transfusion chain to observe, record, analyze and report when something goes wrong. Its mission also includes the use of the acquired knowledge and experience to correct errors and avoid their repeated occurrence ${ }^{(4)}$.

The WHO recommends that the blood-surveillance systems should include monitoring, identification, investigation and analysis of adverse events, near-misses and reactions related to transfusion. This recommendation promotes the creation of notification systems aiming to learn and improve patient safety. Also it identifies a set of characteristics that systems must comply with, including the protection from punishment of the person who registers the notification and protection of his identity. Systems must be independent from the competent authority, and the intention is that the adverse events reporting systems are not recriminatory ${ }^{(5)}$.

Based on the recognition of their potential in improving transfusion practice, and based on the assumptions described above, national hemovigilance systems were emerging all over the world, and particularly in Europe. In Figure 2, some examples of countries that have embraced this initiative are shown.

\section{Conclusions}

The perception of the impact of preventable transfusion errors became the guidance gear for organizational policies, from the top to the bottom, undergoing a review process that must be focused on prevention rather than on correction. Promotion within health institutions of a "fair culture" of the error and awareness of the professionals involved in the transfusion process are essential to ensure a successful change. rem ao longo de toda a cadeia transfusional e, podem ter um impacto negativo na saúde do doente. Os erros podem desencadear reacções adversas no doente com consequências variáveis, que podem ir desde situações 'minor', passando por diversos estados de morbilidade e até à morte. Mas os erros podem ser detectados antes de se iniciar a transfusão e, como tal, não chegam a atingir o doente. Neste caso referimo-nos a quase-erros. E embora estes não tenham consequências, são uma importante fonte de informação e de aprendizagem, que permite identificar as fragilidades do processo com possibilidade de o reestruturar atempadamente, criando barreiras de prevenção.

\section{Hemovigilância: instrumento de monitorização da segurança transfusional}

Foi com base nestas preocupações que surgiu no início dos anos 90, a par da segurança do doente, a hemovigilância como conceito de segurança.

A UE define Hemovigilância como um sistema organizado para observar, registar, analisar e reportar quando algo corre mal na cadeia transfusional. Tendo também a missão de usar os conhecimentos e experiência adquiridos para corrigir os erros e evitar a sua repetição ${ }^{(4)}$.

A OMS recomendou a criação de sistemas de hemovigilância que devem incluir monitorização, identificação, investigação e análise de eventos adversos, quase-erros e reacções transfusionais relacionadas com a transfusão. Esta recomendação promove a criação de sistemas de notificação que visem a aprendizagem e a melhoria da segurança dos doentes. Identifica também um conjunto de características que estes sistemas devem respeitar, nomeadamente o facto de quem regista não ser punido, os sistemas devem ser independentes da autoridade com competência para punir e que a identidade de quem regista não deve ser divulgada. $\mathrm{O}$ que se pretende é que os sistemas de notificação de incidentes e eventos adversos não sejam recriminatórios ${ }^{(5)}$.

Com base no reconhecimento das potencialidades destes sistemas na melhoria da prática transfusional, e assente nas premissas acima descritas, que foram surgindo um pouco por todo o mundo, e em particular na Europa, sistemas de hemovigilância nacionais. Na figura 2 encontram-se exemplos de alguns países que aderiram a esta iniciativa.

\section{Conclusões}

A percepção do impacto dos erros transfusionais evitáveis torna-se assim a engrenagem para a orientação de políticas organizacionais, desde o topo até à base, que passam por uma revisão de processos que deve estar centrada na prevenção e não na correcção. A promoção de uma cultura positiva/justa (just culture) do erro nas instituições de saúde e a sensibilização dos profissionais envolvidos no processo transfusional é essencial para o sucesso da mudança. 
Patient safety in transfusion medicine shall be an organizational priority. For this is not only important to know the reality and communicate results, but also to learn from them.

Avoidable errors are very common and although the majority do not reach the patient, every error has that potential. Hence the near-misses are an important learning tool, since they allow knowledge of the weaknesses of the process and their correction in a timely manner, without jeopardizing patient safety.

Avoidable transfusion errors correspond to human errors performed by the professionals involved in the transfusion chain. As making mistakes is part of the human condition, it is also a human condition to create mechanisms for their reduction, always keeping in mind that although zero risk does not exist, we might be able to get very close to it.
A segurança do doente em medicina transfusional deve constituir uma das prioridades organizacionais, para tal é importante não só conhecer a realidade e comunicar os resultados, como também aprender com eles.

Os erros evitáveis são muito frequentes e embora a maioria não alcance o doente, todos têm esse potencial. Daí que os quase-erros sejam um importante instrumento de aprendizagem, pois conhecer os quase-erros permite conhecer as fragilidades do processo e atempadamente corrigi-las sem colocar em risco a segurança do doente.

Os erros transfusionais evitáveis correspondem a erros humanos cometidos pelos profissionais envolvidos em toda a cadeia transfusional e sem excepção. E uma vez que errar faz parte da condição humana, também é uma condição humana criar mecanismos para a sua redução, sempre conscientes de que o risco zero não existe mas que somos capazes de nos aproximarmos dele.

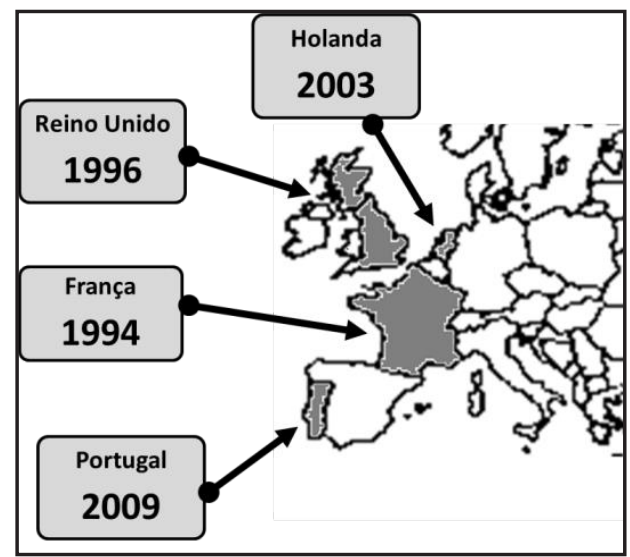

Figure 2/ Figura 2. Examples of some European countries where blood-surveillance systems were implemented

Exemplos de alguns países europeus onde foram implementados sistemas de hemovigilância.

\section{Acknowledgements}

To supervisors Vasco Reis and Paulo Sousa.

\section{Conflict of Interest}

The author declares that no financial or personal relationships that could be interpreted as a potential conflict of interest.

\section{Agradecimentos}

Aos meus orientadores Vasco Reis e Paulo Sousa.

\section{Conflito de Interesses}

A autora declara que não existem relações financeiras ou pessoais que podem ser entendidas como um potencial conflito de interesses. 


\section{References/ referências}

(1) IOM. To Err is Human: Building a safer health system; 1999.

(2) Sousa, P. (2006). PATIENT SAFETY: A Necessidade de uma Estratégia Nacional. Acta Med Port, 19, 309-318.

(3) The Joint Comission International. (Maio de 2007); in: URL: http:// pt.jointcommissioninternational.org/enpt/ WHO-Collaborating-Centre-for-PatientSafety-Solutions/

(4) União Europeia. Optimal Blood Use. (2010); in: URL: http://www.optimalblooduse.eu/ sites/optimalblooduse.eu/files/blood_use manual.pdf

(5) OMS. Blood Transfusion Safety: Haemovigilance. (2010); in: URL: http://www.who.int/ bloodsafety/haemovigilance/en/ 